UDC 621.01

S.O. Koshel, PhD, Assoc.Prof.,

G.V. Koshel, $\mathrm{PhD}$, Assoc.Prof.

Kyiv National University of Technologies and Design, 2 Nemirovich-Danchenko Str., 01011 Kyiv, Ukraine; e-mail: a_koshel@ukr.net

\title{
DETERMINATION OF BASE-LINK COMPLEX PLANAR MECHANISMS’ POINTS VELOCITIES USING GRAPHIC-ANALYTICAL METHOD
}

\begin{abstract}
С.О. Кошель, Г.В. Кошель. Визначення швидкостей точок базисної ланки складних плоских механізмів графоаналітичним способом. Складні багатоланкові плоскі механізми все частіше застосовуються в технологічному обладнанні легкої промисловості. Відсутність універсального способу кінематичного дослідження таких механізмів дозволяє стверджувати, що роботи з кінематичного аналізу багатоланкових механізмів $є$ актуальними. Метою дослідження є розробка послідовностей дій для кінематичного дослідження швидкостей точок базисної ланки складного плоского механізму графоаналітичним способом, що базується на положеннях курсу теоретичної механіки про миттєвий центр швидкостей ланок механізму, які мають плоскопаралельний рух. Визначено вектори швидкостей точок базисної ланки групи Ассура третього класу третього порядку складного плоского механізму графоаналітичним методом, в якому визначаються положення миттєвих центрів швидкостей шатунів механізму, що призводить до зменшення об’єму графічних побудов та, як наслідок, збільшення їх точності.
\end{abstract}

Ключові слова: механізм, кінематичне дослідження, вектор швидкості, план швидкостей.

S.O. Koshel, G.V. Koshel. Determination of base-link complex planar mechanisms' points velocities using graphic-analytical method. The complex planar multilink mechanisms are in increasingly wide use at light industry process equipment. With respect to the lack of a universal method for these mechanisms' kinematic studies evident is the relevance of multilink mechanisms' kinematic analysis. This research was purposed onto developing an operational sequence for kinetic research of a complex planar mechanism's base link points' velocities using a graphic-analytical method departing from the theoretical mechanics' provisions about instantaneous velocity center of the mechanism links, moving by plane-parallel model. The base-link points' velocity vectors of the Assur group third class third order for complex planar mechanisms have been analyzed by graphic-analytical method, determining the position of instantaneous rotation centers of mechanism connecting rods. This reduces the amount of graphical constructs consequently increasing their accuracy.

Keywords: mechanism, kinematic research, velocity vector, plan of the velocity vectors.

Introduction. The modern light industry machines, do largely use the levered action mechanisms, as these ones do provide both high accuracy and speed of mechanisms operation. The modern light industry technological machinery is characterized by the following features:

- High speed of the machine's operative devices motion;

- High accuracy and interaction between various working bodies;

- Complex nature of some working bodies' movement: one movement cycle may include one or two mechanism halting at a certain point for a preset time period when reaching certain specified positions;

- Complex motion path of many technological machines' executive bodies.

Namely these requirements are ultimately satisfied by complex planer multilink mechanisms, still their kinematics analysis problems are insufficiently developed.

Analysis of recent research and publications. The complex planar mechanisms' advantages when compared to others, led to their wide use at industrial machines despite of insufficient structural, kinematic and force-distribution analysis. The gap between these mechanisms' practical use and theoretical studies is evident at investigation of last decades' publications: a significant number of researches is devoted to the analysis of complex multilink mechanisms. Some of them deal with these mechanisms' structure theory [1], other issues do investigate the planar multilink mechanisms' force

DOI 10.15276/opu.2.46.2015.07

(C) 2015 The Authors. This is an open access article under the CC BY license (http://creativecommons.org/licenses/by/4.0/). 
distribution and kinematic analysis [2], in particular studying the mechanisms used at light industry [3, 4]. Remain topical researches examining the kinematic study of complex planar mechanisms using any other possible analytical methods. This is due to the fact that when analysing the variety of upper complexity classes' mechanisms we can not determine the universal research technique. In each case the upper class' complex mechanisms study requires to implement a stepwise sequence related to the simultaneous use of multiple kinematic research methods.

The Aim of the Research is to develop action sequences for investigating the kinematics of a complex planar mechanism's base-link points velocity using a graphic-analytical method, based on the determining the positions of the mechanism rods' instantaneous velocity centers.

Main Body. Let us consider the third class complex planar mechanism (Fig. 1), consisting of the initiating mechanism (links $0 \ldots 1$ ) and links 2, 3, 4, 5, together with kinematic pairs $A, B, N, D, K, C$ forming the third class third order Assur group.
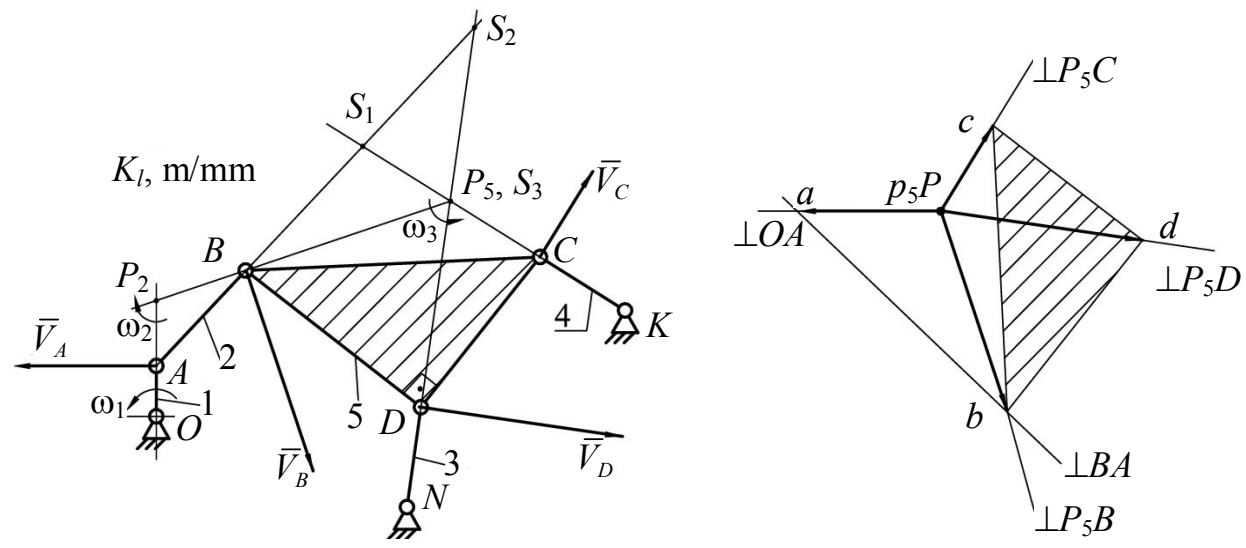

Fig. 1. Kinematic scheme and complex mechanism velocities' diagram (variance 1)

Input parameters for the mechanism kinematic study include the link 1 angular velocity $\left(\omega_{1}=\right.$ const, $\left.\mathrm{s}^{-1}\right)$ and scale of the mechanism kinematic scheme lengths $\left(K_{l}, \mathrm{~m} / \mathrm{mm}\right)$.

We use graphic-analytical method of kinematic study. To solve the problem we apply basic assumptions of the mechanisms' analysis kinematics theory, theory of mechanisms and machines and the theoretical mechanics provisions concerning the study of planar-parallel solid body motion.

Determining the complex mechanism's points kinematic parameters we use the velocities instantaneous center (VIS) $P_{5}$ of the rod 5, whose position is determined using this link's two points $C, D$ vector that link moving in a planar direction. At the same time these point $C, D$ belong to two cams 3 , 4 (kinematic pairs $C, D$ are formed correspondingly by links 5,4 and 5,3 ) so the velocity vectors are directed as: $\vec{V}_{C} \perp C K, \vec{V}_{D} \perp D N$. The $P_{5}$ point is located at the intersection of lines departing correspondingly from the points $C$ and $D$ in directions $P_{5} C \perp \vec{V}_{C}, P_{5} D \perp \vec{V}_{D}$. Now we shall determine the velocity direction of the third grade Assur group basic link third point. $\vec{V}_{B} \perp P_{5} B$. To investigate the kinematic parameters (velocities) of the complex link 5 points using graphic-analytical method we adopt the instantaneous rotational movement of the connecting rod 5 around the VIS - point $P_{5}$ (the angular velocity $\omega_{5}$ direction is chosen arbitrarily, for example, counter-clockwise). Attention is drawn to the fact that the $P_{5}$ point position coincides with the position one from among possible special Assur points $S_{3}$ of the third class links' group. It is clearly observable for the other two options of mechanisms' structured on the basis of third order third group Assur group the $P_{5}$ coincides with the position of other possible Assur special points $S_{1}$ and $S_{2}$ : the VIS point match to $S_{1}$ if driving link 1 is connected to the link 3, and to $S_{2}$ point, when the crank 1 is attached to the link 4 .

The velocities' plans shaping (Fig. 1) starts with the $\vec{P} b$ vector departing from pole $P$ onto an arbitrary length considering the $\omega_{5}$ selected angular velocity, along the direction perpendicular to $P_{5} B$ segment that connects point $B$ with the link's 5 VIS. 
We form a system of speed vector equations $\vec{V}_{A}, \vec{V}_{B}, \vec{V}_{B ; A}, \vec{V}_{A ; O}$ for point A, given that the point speed which coincides with a kinematic pair formed by crank 1 and the support, is equal to $0\left(V_{O}=0\right)$ :

$$
\left\{\begin{array}{c}
\vec{V}_{A}=\vec{V}_{B}+\vec{V}_{B ; A}, \\
\vec{V}_{A}=\vec{V}_{A ; O}
\end{array},\right.
$$

where $\vec{V}_{B ; A} \perp B A, \vec{V}_{A ; O} \perp A O$.

Resolving the system of vector equations (1) graphically we define the " $a$ " point position and the $A$ point absolute velocity vector $\left(\vec{V}_{A}=\vec{P} a\right)$ on the velocities' diagram, which is built in an uncertain scale.

On the other hand, the $A$ point's absolute velocity value is found using the conditions of that point association to the mechanism's driving link, the angular velocity $\omega_{1}$ being given with

$$
V_{A}=\omega_{1} \cdot l_{O A},
$$

where $l_{O A}$ - crank's length, $\mathrm{m}$.

Now we proceed to calculate the actual value of velocities' scale $K v$.

It should be noted that when the resulting linear speed direction vector of point $A$ does not meet the specified direction of angular velocity $\omega_{1}$, it is necessary to adjust the length of $P b$ interval and (or) to change the chosen complex link's 5 direction of angular velocity $\omega_{5}$ into opposite one and proceed anew to the diagram tracing.

To determine the link's 5 points' $C, D$ linear velocity we apply the theoretical mechanics theorem on determining the points' velocities of a solid body under planar motion using VIS: the linear speed of all points at this link represent values proportional to the distances from those points of the body to VIS position.

The positions of points $c, d$ on that diagram are found from conditions for the given vectors' directions $\left(\vec{V}_{D} \perp P_{5} D ; \vec{V}_{C} \perp P_{5} C\right)$ and numeric proportion

$$
\frac{P b \cdot K v}{P_{5} B}=\frac{P c \cdot K v}{P_{5} C}=\frac{P d \cdot K v}{P_{5} D} .
$$

Let us calculate the base link 5 points $B, C, D$ linear velocities value on the scale of the $K v$ plan.

To be noted is that for the velocities' plane construction we can apply another actions sequence, namely using the fact that the kinematic pair $B$ is formed by two connecting rods, whose $P_{5}$ and $P_{2}$ points' position can be determined.

So, the link's VIS can be found at the intersection of two lines drawn from points $A$ and $B$ respectively in direction $P_{2} A \perp \vec{V}_{A}$ and $P_{2} B \perp \vec{V}_{B}$ (Fig. 1). Then the further actions' sequence will be as follows: we build a vector $\vec{P} a$ of arbitrary length and determine its scale $K v$.

We apply the theorem of similarity to the three points $A, B, P_{2}$ of the connecting rod 2, whereby the ratio between values of the mechanism position plane and of velocities plane segments serve to define the largest segment $P b$, whose direction is $P b \perp P_{2} B$. The $C, D$ points' velocities are found using VIS of the link 5 and the angular velocity $\omega_{5}$, which is defined by linear speed $V_{B}$.

The above exposed methods of kinematic study are useful when the complex link 5 two points' velocity vectors direction is set in an explicit or an implicit form. In this example, the kinematic pairs $D, C$ are formed on one side by the rod 5 , and on the other by the two cams 3,4 . The direction of the $D, C$ points' velocity vectors is caused by the rotational movement of links 3,4 respectively to their axes of rotation.

At the fourth' and higher complexity classes' mechanisms determining the velocity vectors direction for two points of any connecting rod is not easy, as at such mechanisms they are connected to each other forming together a closed path of motion (closed moving contours).

Factors acting in complexity aggravating when determining the position of rods' VIS points include the links' structural groups order: the unchanged number of links included to the Assur group 
when their class number greater, can become of lesser order, that is decreased is the number of mechanism's points with predetermined kinematic parameters used to find the links' VIS position. In this case, to determine the position of a link's VIS point recommended is to use two specific singular points of a complex links within the Assur group, choosing the points whose velocity vectors can be found using their direction and value.

Here we define the position of link's 5 specific points $S_{1}, S_{2}$ (Fig. 2) as these representing the pairwise intersection between respective belts' axial lines $A B, C K$ and $A B, D N$
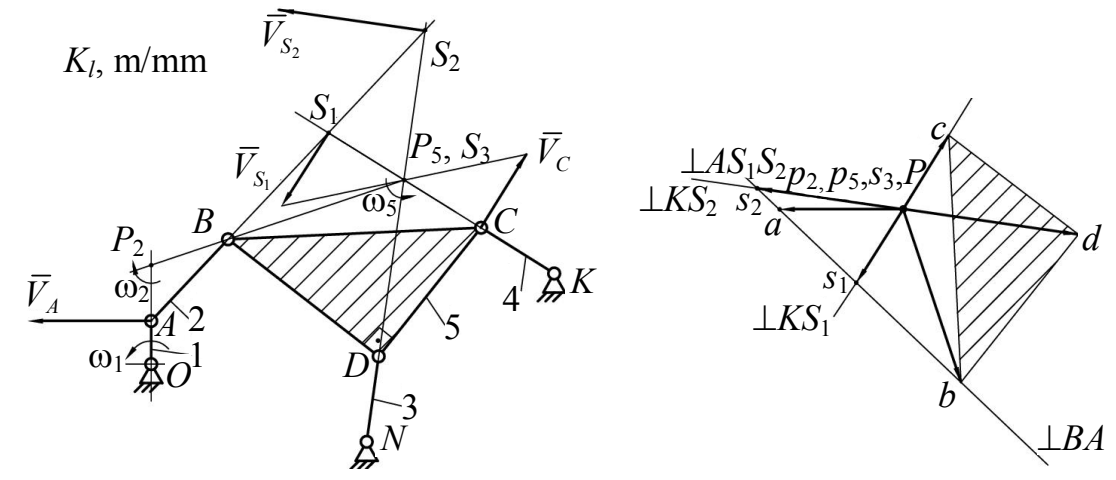

Fig. 2. Kinematic scheme and complex mechanism velocities' diagram (variance 2)

We compose two systems of vector equations that allow determining at velocities plane the position of $S_{1}, S_{2}$ points serving as ends of $\vec{V}_{S 1}$ and $\vec{V}_{S 2}$ velocity vectors

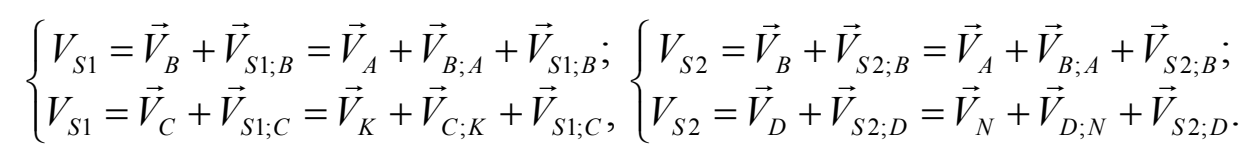

The found velocity vectors $\vec{P}_{S 1}, \vec{P}_{S 2}$ are respectively drawn from the points $S_{1}, S_{2}$ on the mechanism position plane. Their directions serve to define the position of $P_{5}$ point as VIS of link 5. Now we can calculate the $\omega_{5}$ angular velocity value and linear velocities of complex link's 5 all points.

Results. The advantage of this kinematic analysis method compared to other ones is that the VIS position for one of the mechanism's links can be determined using this link's special points whose position, in turn, is determined by special points of other links for which we can calculate these points "velocities by the value, direction and position of kinematic pairs which are connecting the rods that form a closed path in a complex mechanism.

Conclusions. Researched are the third class complex planar mechanism basic link points velocities using methods, departing from techniques of determining the velocity instantaneous centers units, of links under planar movement. This allows us to optimize the graphic constructions' volume and, consequently, to increase their accuracy. The proposed methods can be recommended for similar studies of fourth and higher complexity class mechanisms when closed notion path (contours).

\section{Література}

1. Кикин, А.Б. Аналитико-оптимизационный синтез шестизвенного механизма с выстоем / А.Б. Кикин, Э.Е. Пейсах // Изв. ВУЗов. Технология текстильной промышленности. — 2008. № 5(311). - С. $79-83$.

2. Дворников, Л.Т. Исследование кинематики и кинетостатики плоской шарнирной шестизвенной группы Ассура с четырехугольным замкнутым изменяемым контуром / Л.Т. Дворников, С.П. Стариков // Изв. ВУЗов. Машиностроение. - 2008. - № 4(595). - С. 3 - 10.

3. Гебель, Е.С. Моделирование кинематики механизма игл основовязальной машины / Е.С. Гебель, Е.В. Солонин // Сб. мат. Х междунар. науч.-практ. конф. «Теоретические знания в практические дела»: в 2 ч. - Омск, 2009. - Ч. 2. - С. $211-215$. 
4. Кикин, А.Б. Синтез рычажных механизмов для привода нитераскладчика мотальной машины / А.Б. Кикин // Изв. ВУЗов. Технология текстильной промышленности. - 2005. — № 1(282). C. $115-119$.

\section{References}

1. Kikin, A.B. and Peisakh, E.E. (2008). Analytical-optimizational synthesis of six-linking mechanism with dwell. Proceedings of Higher Education Institutions. Textile Industry Technology, 5, 79-83.

2. Dvornikov, L.T. and Starikov, S.P. (2008). The study of kinematics and kinetostatics of the flat sixsection group of Assur of the fourth class with quadrangular closed changeable contour. Proceedings of Higher Educational Institutions. Machine Building, 4, 3-10.

3. Gebel, E.S. and Solonin, E.V. (2009). Kinematics modeling of needle mechanism of warp-knitting machine. In Proceedings of $10^{\text {th }}$ International Scientific and Practical Conference "Theoretical Knowledge into Practice” (Vol. 2, pp. 211-215). Omsk: MSUTM named after K.G. Razumovsky.

4. Kikin, A.B. (2005). Linkages synthesis to drive of the thread spreading for a winding machine. Proceedings of Higher Education Institutions. Textile Industry Technology, 1, 115-119. 